\title{
Molecular identification of the stem rust resistance genes in the introgression lines of spring bread wheat
}

\author{
O.A. Baranova ${ }^{1} \otimes$, S.N. Sibikeev ${ }^{2}$, A.E. Druzhin ${ }^{2}$ \\ ${ }^{1}$ All-Russian Institute of Plant Protection, Pushkin, St. Petersburg, Russia \\ ${ }^{2}$ Agricultural Research Institute of the South-East Region, Saratov, Russia \\ 凶e-mail: baranova_oa@mail.ru
}

\begin{abstract}
A total of 57 introgression lines and 11 cultivars of spring bread wheat developed by All-Russian Institute of Plant Protection and cultivated in the Volga Region were analyzed. The lines were obtained with the participation of CIMMYT synthetics, durum wheat cultivars, direct crossing with Agropyron elongatum (CI-7-57) and have introgressions from related species of bread wheat, namely translocations from Ag. elongatum (7DS-7DL-7Ae\#1L), Aegilops speltoides (2D-2S), Ae. ventricosum (2AL-2AS-2MV\#1), Secale cereale (1BL-1R\#1S), 6Agi (6D) substitution from Ag. intermedium and triticale Satu. Cultivars and lines were assessed for resistance to Saratov, Lysogorsk, Derbent and Omsk stem rust pathogen populations (Puccinia graminis f. sp. tritici), and analyzed for the presence of the known Sr resistance genes using molecular markers. The analysis of the cultivars' and lines' resistance to the Saratov pathogen population in the field, as well as to Omsk, Derbent and Lysogorsk populations at the seedling stage, showed the loss of efficiency of the Sr25 and $\mathrm{Sr}_{\mathrm{A} A g^{i}}$ genes. The $\mathrm{Sr} 31$ gene remained effective. Thirty one wheat lines out of 57 (54.4\% of samples) were resistant to all pathogen populations taken into analysis. The Sr31/Lr26, Sr25/Lr19, $S r 28, S r 57 / L r 34$ and Sr38/Lr37 genes were identified in the introgression lines. The Sr31/Lr26 gene was identified in 19 lines (33.3\% of samples). All lines carrying the 1RS.1BL translocation ( $\mathrm{Sr31/Lr26)}$ ) were resistant to all pathogen populations taken into analysis. The Sr25/Lr19 gene was identified in 49 lines (86\%). The gene combination Sr31/Lr26+ Sr25/Lr19 was identified in 15 lines (26.3\%). The gene combinations Sr38/Lr37+Sr25/Lr19, Sr57/Lr34+Sr25/Lr19 and $S r 31 / L r 26+S r 25 / L r 19+S r 28$ were identified in 3 introgression lines. These three lines were characterized by resistance to the pathogen populations studied in this work. The Sr2, Sr24, Sr26, Sr32, Sr36 and Sr39 genes were not detected in the analyzed wheat lines.

Key words: spring bread wheat; introgression lines; Puccinia graminis f. sp. tritici; Sr genes.
\end{abstract}

For citation: Baranova O.A., Sibikeev S.N., Druzhin A.E. Molecular identification of the stem rust resistance genes in the introgression lines of spring bread wheat. Vavilovskii Zhurnal Genetiki i Selektsii =Vavilov Journal of Genetics and Breeding. 2019;23(2):296-303. DOI 10.18699/VJ19.494

\section{Молекулярная идентификация генов устойчивости к стеблевой ржавчине в интрогрессивных линиях яровой мягкой пшеницы}

\author{
О.А. Баранова ${ }^{1}$ 이, С.Н. Сибикеев ${ }^{2}$, А.Е. Аружин ${ }^{2}$ \\ ${ }^{1}$ Всероссийский научно-исследовательский институт защиты растений, Пушкин, Санкт-Петербург, Россия \\ 2 Научно-исследовательский институт сельского хозяйства Юго-Востока, Саратов, Россия \\ هe-mail: baranova_oa@mail.ru
}

Проанализированы 57 интрогрессивных линий и 11 сортов яровой мягкой пшеницы селекции НИИ сельского хозяйства Юго-Востока, возделываемых на территории Поволжья. Линии получены с участием синтетиков селекции СІММYТ, сортов твердой пшеницы, прямого скрещивания с Agropyron elongatum (Cl-7-57) и имеют интрогрессии от родственных видов мягкой пшеницы, а именно транслокации от Ag. elongatum (7DS-7DL7Ae\#1L), Aegilops speltoides (2D-2S), Ae. ventricosum (2AL-2AS-2MV\#1), ржи культурной (1BL-1R\#1S), замещения от Ag. intermedium 6Agi (6D) и тритикале Satu. Сорта и линии были оценены на устойчивость к саратовской, лысогорской, дербентской и омской популяциям возбудителя стеблевой ржавчины, а также проанализированы на наличие идентифицированных $\mathrm{Sr}$ генов устойчивости с использованием известных молекулярных маркеров. Анализ устойчивости сортов и линий к саратовской популяции патогена в полевых условиях, а также к омской, дербентской и лысогорской популяциям Puccinia graminis f. sp. tritici на стадии проростков показал потерю эффективности генов Sr25 и Sr6Ag. Ген Sr31 пока сохраняет свою эффективность. Ко всем взятым в анализ популяциям патогена была устойчива 31 линия пшеницы из 57 (54.4 \% образцов). У исследуемых интрогрессивных линий идентифицированы гены Sr31/Lr26, Sr25/Lr19, Sr28, Sr57/Lr34 и Sr38/Lr37. Ген Sr31/Lr26 определен у 19 линий (33.3 \% образцов). Все линии, несущие транслокацию 1RS.1BL (Sr31/Lr26), были устойчивы ко всем взятым в анализ популяциям патогена. Ген Sr25/Lr19 идентифицирован у 49 линий 
(86 \% образцов). Сочетание генов Sr31/Lr26+Sr25/Lr19 идентифицировано у 15 линий (26.3 \%). У одной линии идентифицировано сочетание генов Sr38/Lr37+Sr25/Lr19, у другой линии - сочетание генов Sr57/Lr34+ $+S r 25 / L r 19$, и еще у одной - Sr31/Lr26+Sr25/Lr19+Sr28. Все они были устойчивы ко всем взятым в анализ популяциям патогена. Гены Sr2, Sr24, Sr26, Sr32, Sr36, Sr39 у анализируемых линий обнаружены не были.

Ключевые слова: яровая мягкая пшеница; интрогрессивные линии; Puccinia graminis f. sp. tritici; гены Sr.

\section{Introduction}

In recent years, the increasing severity of wheat stem rust (caused by the biotrophic fungus Puccinia graminis Pers. f. sp. tritici Eriks. and E. Henn.) both on the territory of Africa and America, and countries of the Eurasian continent is observed. The emergence of the new highly aggressive stem rust race in Uganda in 1999 - Ug99 (TTKSK), infecting wheat cultivars which contain gene $S r 31$ (Pretorius et al., 2000), caused great concern of world wheat producers, because with epiphytotic development of this pathogen on susceptible cultivars yield losses can reach $100 \%$ (Hailu et al., 2015). Currently, there are 13 biotypes of this race (http://rusttracker.cimmyt. org/?page_id=22). The Ug99 race is common in the countries of Africa and the Middle East, it spread in the direction of Central and Southeast Asia and it is possible to spread it into the territory of the Russian Federation.

On the other hand, new aggressive races of stem rust that differ from Ug99 have appeared in the world. So, in 2012 in Ethiopia, a new race TKTTF was identified and called Digalu, after the name of the wheat cultivar that it overcome. Crop losses of this cultivar in 2013-2014 reached almost $100 \%$. In Germany during 2013, 6 races: TKTTF, TKKTF, TKPTF, TKKTP, PKPTF and MMMTF, which are not part of the Ug99 racial group, were allocated from 48 isolates of $P$. graminis (Olivera et al., 2017). German isolates of race TKTTF differed from the Ethiopian race TKTTF in virulence to the lines with genes $\mathrm{Sr} 7 \mathrm{a}, \mathrm{Sr} 45$ and $\mathrm{SrTt}$-3. Another isolated race, TKKTP, turned out to be virulent to the lines with the genes $S r 24$, SrTmp and Sr1RSAmigo. It is known that $55 \%$ of North American and international cultivars and breeding lines resistant to the TTKSK race (Ug99) are susceptible to the TKKTP race (Olivera et al., 2017). The TKTTF race is found in the countries of the Middle East and Europe (www.wheatrust. org/stem-rust-tools-maps-and-charts/race-frequency-map), including the UK (Lewis et al., 2018). In 2016, the new race of stem rust (TTTTF) injured several thousand hectares of durum wheat in Sicily. It was the largest epiphytoty of stem rust in Europe in recent decades. The race TTTTF is virulent to the lines with the genes $\mathrm{Sr} 9 e, \mathrm{Sr} 13$ and avirulent to the genes $\operatorname{Sr} 31$, Sr24 and Sr25 (Bhattacharya, 2017). Also in 2016 in Ecuador, the race RRTTF virulent to genes $\mathrm{Sr} 38$ and $\mathrm{Sr} 13$ was discovered which became a real threat to wheat production in North and South America, since much of the modern commercial cultivars turned out to be susceptible to it. The origin of the race RRTTF in Ecuador is unknown; earlier race RRTTF was identified in Asia (Pakistan), East Africa (Ethiopia) and the Middle East (Yemen) (http://rusttracker. cimmyt.org/? $p=7143$ ). In the summer of 2017 in Sweden, the epiphytotic development of stem rust was observed in wheat fields of Almunge, Uppland. Moreover, the last major epiphytotics of stem rust in Sweden was in 1951. In 2015, 2016, epiphytotic development of stem rust was observed in northern Kazakhstan (Koyshybaev, 2017).
On the territory of the Russian Federation, the epiphytotic development of the disease was noted in 2015, 2016 and 2017 in Western Siberia, the Central Region of the European part of the Russian Federation and in Lower Volga Region. In 2016, race TTTTF different from the Sicilian race was identified in Western Siberia (according to Global Rust Reference Center http://wheatrust.org/fileadmin/www. grcc.au.dk/International_Services/Pathotype_SR_Results/ Country_report_Russia_-_August2017.pdf). In the Lower Volga Region on the territory of the Saratov Oblast, the strong epiphytotics of stem rust was observed in 2004 and 2006 , the severity of disease development was 50-60\%, in 2013-2014 the severity of disease was moderate, up to $30 \%$ (Markelova, 2015). However, in 2016 in the Saratov Oblast, especially in the Right-Bank part of Volga river, epiphytotic of stem rust began during the milky ripeness of the grain (early July) and continued until full maturity and harvest. The degree of development reached $80 \%$, the affected cultivars reduced the yield by $50 \%$, and the mass of 1000 seeds was at the level of 18-19 grams (Sibikeev et al., 2017b; Sibikeev, unpubl. data). Also in 2016, the spread of stem rust on spring bread wheat in the period of earing was noted throughout the territory of the Republic of Tatarstan. All wheat cultivars, recommended for cultivation in Tatarstan, were susceptible, except for the Tulaikovskaya 5 and Belka cultivars, as well as samples of Triticum dicoccum (Vasilova et al., 2017).

It should be noted that often there is an alternation of years with epiphytoties of stem rust with the years of epiphytotic development of leaf rust. So in the Saratov region, as already noted, in 2016 the strong stem rust epiphytotics, and in 2017 the strong leaf rust epiphytotics were observed. Thus, in order to prevent economically significant losses, the cultivars and promising lines with resistance to both diseases are necessary, that complicates the breeding work and may lead to the narrowing of genetic diversity. Complexes (linkages) of genes that determine resistance to stem, leaf and yellow rust and powdery mildew of various origins, including introgressed from related species, take on special significance.

Wild relatives of wheat are the valuable reservoir of genetic diversity (Wulff, Moscou, 2014). Studies of introgression lines and the use of their genetic potential in the breeding process are carried out both in Russia (Salina et al., 2015; Baranova et al., 2016; Lapochkina et al., 2017; Leonova, Budashkina, 2017; Sibikeev et al., 2017a) and abroad (Wulff, Moscou, 2014; Ali et al., 2016; Rakszegi et al., 2017). Molecular markers are widely used to identify alien introgression and loci for economically valuable traits, including resistance to disease genes (Miedaner, Korzun, 2012; Leonova, 2013; Yaniv et al., 2015; Ali et al., 2016).

The aim of this work was to evaluate the spring bread wheat cultivars and introgression lines by ARISER breeding and widespread in the Lower Volga Region, for resistance to 
leaf and stem rust, and to identify effective $S r$ genes using molecular markers.

\section{Materials and methods}

Phytopathological analysis. Breeding material from the ARISER (57 introgression lines) and 11 cultivars of spring bread wheat which cultivated in the Volga Region and related to the analyzed lines were used in this work. All lines were obtained with the participation of genetic material from related species of bread wheat, namely, translocation from tall wheatgrass Agropyron elongatum (7DS-7DL-7Ae\#1L), substitution from intermediate wheatgrass $\mathrm{Ag}$. intermedium $\left(6 \mathrm{Ag}^{\mathrm{i}}(6 \mathrm{D})\right)$, rye Secale cereale (1BL-1R\#1S), and also with the participation of synthetic lines from CIMMYT, cultivars of durum wheat, translocations from Aegilops speltoides (2D-2S), Ae. ventricisum (2AL-2AS-2MV\#1), triticale Satu and direct crossing with tall wheatgrass Ag. elongatum ( $2 n=70)$ CI-7-57.

The Omsk, Derbent, and Lysogorsk populations of the pathogen, collected in 2017 from the spring bread wheat cultivar Favorit, which carries the 6Ag ${ }^{\mathrm{i}}$ (6D) substitution, were used for laboratory evaluation of resistance at the seedling stage. Virulence of populations was evaluated using the set of 20 differentiators (North American differential set) (Cereal Disease Laboratory) and additional near isogenic lines (21 lines) (Suppl. Material 4) ${ }^{1}$. The cultivars Avrora (gene Sr31) and Hakasskaya (susceptible control) were also used in the analysis. Inoculation of plants was carried out in accordance with the methods adopted in world practice (Jin et al., 2007) (http://www.fao.org/fileadmin/templates/rust/img/ race_analysis_web.pdf).

The analyzed samples were grown in plastic cuvettes of size $11 \times 15 \times 6 \mathrm{~cm}$ filled with "Terra Vita" peat soil, using grow light systems, at $21-23{ }^{\circ} \mathrm{C}$ with a 14 -hour photoperiod. Eleven samples (three plants per sample) plus susceptible control wheat cultivar Hakasskaya, were placed in a cuvette. Ten-day old seedlings with the first leaf fully unfolded were inoculated with the urediniospores suspension of pathogen populations collected from the cultivar Favorit in 2017. Infectious load was $1 \mathrm{mg}$ of spores in $1 \mathrm{ml}$ (Singh et al., 2008). $5 \mathrm{ml}$ of spore suspension was used per cuvette (12 samples $=36$ plants), which was approximately $0.14 \mathrm{mg}$ spores per plant. Inoculated plants were placed in the dark moist chambers for 16 hours at $21-23{ }^{\circ} \mathrm{C}$ and a relative humidity of $100 \%$, and then returned to the grow light system with same temperature. The reaction of seedlings to inoculation (IT) with the spores suspension of stem rust pathogen was taken into account on the 10-12th day after infection on the standard scale (Stackman et al., 1962) (Suppl. Material 5). The resistance or susceptibility of the sample was judged based on the types of reaction (IT) in two replications. Plants with ITs " 0 ", " 0 ;", "1", " 2 ", "X" were considered as resistant and as susceptible with IT = " 3 ", " 4 ". As criteria for evaluation of adult plants resistance were the ITs and the degree of plant damage on the scale recommended by CIMMYT (Roelfs et al., 1992): R - resistance to infection; $\mathrm{MR}$ - medium resistance; $\mathrm{MS}$ - medium susceptibility; $\mathrm{S}$ - susceptible reaction.

DNA isolation and PCR analysis. DNA was isolated from five-day wheat seedlings using cetyltrimethylammonium bro-

${ }^{1}$ Supplementary Materials 1-8 are available in the online version of the paper: http://www.bionet.nsc.ru/vogis/download/pict-2019-23/appx5.pdf mide (CTAB) (Murray, Thompson, 1980). The composition of the reaction mixtures and the conditions of PCR are presented in the Suppl. Material 2.

DNA markers recommended for marker-assisted selection (MAS) were used to identify resistance genes $(\mathrm{Sr} 2, \mathrm{Sr} 24$, Sr25, Sr26, Sr28, Sr31, Sr32, Sr36, Sr38 and Sr39) (Suppl. Material 1). Amplification was performed on C1000 Thermal Cycler amplifiers (BioRad), separation of PCR products was carried out in $2 \%$ agarose gels with addition of ethidium bromide. Near isogenic lines and cultivars with $\mathrm{Sr}$ genes served as positive control (Suppl. Material 3), susceptible cultivar Hakasskaya served as negative control. GeneRulerTM 50 bp DNA Ladder (Fermentas) was used as a molecular weight marker. The amplification products were visualized using the ChemiDoc ${ }^{\mathrm{TM}}$ XRS + imaging system (Bio-Rad). PCR was carried out in 2 replicates.

\section{Results}

\section{Phytopathological analysis \\ of resistance to causative agent of stem rust}

At the first stage of work, 57 lines and 11 wheat cultivars were evaluated for resistance to the Saratov population of stem rust under field conditions and for resistance to the Derbent, Omsk and Lysogorsk pathogen populations at the seedling stage under laboratory conditions. The stem rust populations were previously evaluated for virulence. Against the Omsk population of 2017, the genes $\mathrm{Sr} 11, \mathrm{Sr} 31, \mathrm{Sr} 13, \mathrm{Sr} 25$, $\operatorname{Sr} 26, \operatorname{Sr} 32, \operatorname{Sr} 35$ and the combinations of genes $\operatorname{Sr} 26+\operatorname{Sr} 9 g$, $\operatorname{Sr} 31+\operatorname{Sr} 36$ and $S r 31+S r 24$ were effective; against Lysogorsk population - Sr13, Sr17, Sr31, Sr26, Sr32, Sr35, Sr24+Sr31, $\operatorname{Sr} 36+\operatorname{Sr} 31, \operatorname{Sr} 24+\operatorname{Sr} 36$ and $S r 26+S r 9 g$; against Derbent population - genes $\mathrm{Sr} 13, \mathrm{Sr} 24, \mathrm{Sr} 25, \mathrm{Sr} 26, \mathrm{Sr} 31, \mathrm{Sr} 35, \mathrm{Sr} 40$ and the combinations of genes $\operatorname{Sr} 24+\operatorname{Sr} 31, \operatorname{Sr} 36+\operatorname{Sr} 31$, $\mathrm{Sr} 24+\operatorname{Sr} 36, \mathrm{Sr} 26+\mathrm{Sr} 9 g$.

All lines were resistant to the Saratov population of stem rust in the field conditions. During evaluation at the seedling stage, 6 lines susceptible to the Derbent pathogen population, 2 lines susceptible to the Omsk pathogen population and 15 lines susceptible to the Lysogorsk pathogen population were identified. Thirty one lines $(54.4 \%)$ were resistant to all the populations taken in the analysis (see the Figure).

From the 11 analyzed cultivars almost all were susceptible in the field - namely: cultivars Saratovskaya 55, Saratovskaya 68, Saratovskaya 70, Saratovskaya 73, Albidum 32, Favorit, Voevoda and Lebyodushka. The cultivars Prokho-

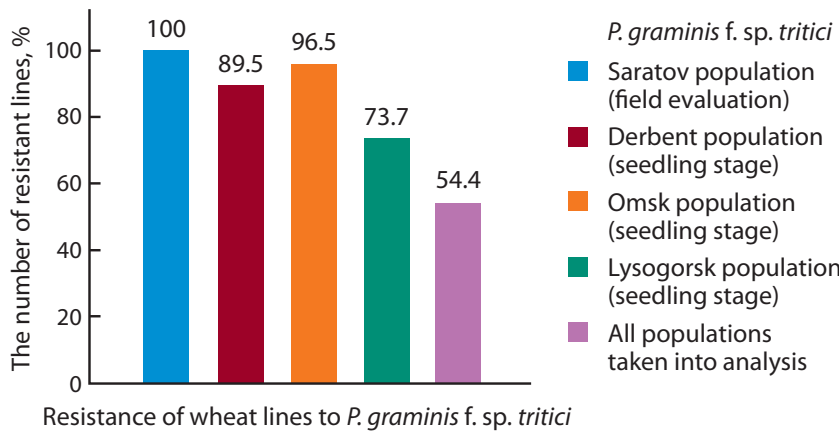

Results of the phytopathological analysis of introgression lines. 
rovka, Yugo-Vostochnaya 2 and Dobrynya were heterogeneous for resistance, the susceptible plants were observed among resistants. During laboratory analysis of cultivars the following results were obtained: Prokhorovka, Yugo-Vostochnaya 2 and Dobrynya cultivars are resistant to the Derbent population of stem rust; the cultivars Prokhorovka, Yugo-Vostochnaya 2, Dobrynya and Saratovskaya 55 are resistant to the Lysogorsk population, the cultivar Saratovskaya 73 turned out to be heterogeneous. Almost all cultivars are resistant to the Omsk pathogen population, Albidum 32, Dobrynya, and Voyevoda are heterogeneous. Heterogeneity for the genes of resistance to stem rust can be explained by the fact that in the breeding process there was no selection for resistance to this disease, which allows for the presence of several biotypes in the cultivar.

\section{Identification of resistance genes}

The gene $\mathrm{Sr} 31$ was identified as gene ineffective to $\mathrm{Ug} 99$, but effective against local stem rust populations. The scm 9 marker, developed for rye translocation 1BL.1RS carrying the gene complex resistant to stem $(\mathrm{Sr} 31)$, leaf $(\mathrm{Lr} 26)$ and yellow $(\mathrm{Yr} 9)$ rust and powdery mildew $(P m 8)$, was used to identify it. The translocation 1BL.1RS (gene Sr31) was identified in 19 lines out of 57 (33.3\%) (Suppl. Material 8). All samples carrying the 1BL.1RS translocation were resistant to the Saratov population of stem rust during the field evaluation and to all analyzed pathogen populations during evaluation of resistance at the seedling stage. The gene Sr31 was identified in the Prokhorovka and Yugo-Vostochnaya 2 cultivars. However, during evaluation of resistance to the Saratov population of pathogen, susceptible plants of these cultivars were identified. A question arose about the possible appearance of fungal pathotypes in the Saratov population of pathogen that virulent to the gene $\operatorname{Sr} 31$. DNA from 10 individual grains of the infected cultivar Prokhorovka was tested for the presence of amplification fragments using the primer scm9 to confirm the present or absence of 1BL.1RS translocation in susceptible plants. Diagnostic fragment $207 \mathrm{bp}$ was obtained only from the control cultivar Avrora (carrier of Sr31) that means the absence of 1RS.1BL (Sr31) translocation in analyzed susceptible plants. According to morphological characteristics (plant height, type of ear) admixture of another plant is unlikely. Moreover, this fact was observed (IT $=0$ and 3 ) at different seed sources, including the original ones, the heterogeneity is most likely as the loss of $1 \mathrm{RS} .1 \mathrm{BL}$ translocation. It was also concluded that the gene $S r 31$ still retains its effectiveness.

The gene $\mathrm{Sr} 25$, which effective for Ug99, was identified in 49 lines $(86 \%)$. For identification this gene was used the Gb marker recommended for the marker-assisted selection. The Sr 25 gene was also identified in the cultivars Dobrynya and the Lebyodushka. The gene $\operatorname{Sr} 38$ was detected only in one line (Tselinnaya20/Dobr//Dobr/3/DobrLr9/4/Milan/Prinia*// 4Dobr) using the VENTRIUP-LN2 primers. In this line, the combination of genes $\mathrm{Sr} 25 / \mathrm{Lr} 19+\mathrm{Sr} 38 / \mathrm{Lr} 37$ was identified (Suppl. Material 7). In one line (L505*2//Croc/Ae.squar(224)// Yaco) using the csLV34 marker in addition to the $S r 25$ gene, the gene of adult resistance Sr57/Lr34 was identified. Both of these lines were resistant to all analyzed populations of pathogen.

In addition, using markers wPt-7004-PCR and Xwmc332, the gene $\operatorname{Sr} 28$ was identified in one of the lines; however, this fact should be verified during further work using other markers. In this line, the combination of the Sr31/Lr26+Sr25/ $\mathrm{Lr} 19+\mathrm{Sr} 28$ genes provided resistance to all analyzed populations of the pathogen. The CAPS marker csSr2 was used to identify the adult plant resistance gene $-S r 2$. Amplification product with primers $\operatorname{csSr} 2 \mathrm{~F} / \mathrm{R}$ was observed in almost all analyzed samples. After restriction of amplification product by restriction endonuclease $B s p H I$, the diagnostic fragment 172 bp was observed only in control cultivars Arthur and Oasis. The genes from Ae. speltoides were not found in the wheat accessions, although the presence of introgressions from this species in the pedigree of lines suggested that genes such as $S r 32$ and Sr39/Lr35 could be present. However, it is likely that specific markers, other than markers for Sr32 and Sr39, are needed for identification the $\mathrm{Sr}$ genes of the studied lines.

Thus, the genes Sr31/Lr26 and Sr25/Lr19 were mainly identified in the introgression lines. The combination of these genes $-\operatorname{Sr} 31+\operatorname{Sr} 25$ was found in 15 lines $(26.3 \%)$. The genes $\mathrm{Sr} 2, \mathrm{Sr} 24$, $\mathrm{Sr} 26, \mathrm{Sr} 32, \mathrm{Sr} 36, \mathrm{Sr} 39$ were not detected in the analyzed lines.

\section{Discussion}

In the Volga region of Russia, one of the factors limiting the grain yield of wheat are the epiphytotics of rust fungi - leaf and stem rust, and the harmfulness of stem rust in recent years has increased significantly. The success of anticipatory breeding for resistance to these pathogens is largely determined by the diversity of used resistance genes. For targeted wheat breeding, the identification of resistance genes in cultivars, identification of their effectiveness and join its in combinations is necessary.

The analyzed in this research cultivars of spring bread wheat occupy over $95 \%$ of the area in the Saratov Oblast and Volgograd Oblast and are also widespread in the Middle Volga Region, Ural Region and partially in the Central Black Soil Region of Russia. Thus, it is their genotypes for rust resistance genes that determine (inhibit or not) the development of the epiphytoties of these pathogens. It should be noted that the substitution of $6 \mathrm{Ag}^{\mathrm{i}}$ (6D) from $\mathrm{Ag}$. intermedium was previously identified in the cultivars Favorit and Voevoda, while the Lebyodushka cultivar had the genes $\operatorname{Sr} 6 A g^{i}+\operatorname{Lr} 19 / \mathrm{Sr} 25$ (combination of substitution $6 \mathrm{Ag}^{\mathrm{i}}(6 \mathrm{D})$ and translocation 7DS-7DL-7Ae\#1L) (Sibikeev et al., 2017a), and the translocation 7DS-7DL-7Ae\#1L from tall wheatgrass with gene $\mathrm{Sr} 25$ / Lr19 was identified in the Dobrynya cultivar (Badaeva et al., 2018). The presence of the gene Sr25 in the Dobrynya and Lebyodushka cultivars is confirmed in this work (Table 1).

It is known that the gene Sr25 (cultivars L503, L505, Dobrynya) showed the susceptible type of reaction and the percentage of lesion was 15-20\% in 2006, and in 2016 the IT $=2,3$ and degree of lesion was $15-25 \%$. For the gene(s) $\mathrm{Sr}_{\mathrm{Ag}}{ }^{i}$ (cultivars Belyanka, Favorit, Voevoda) in $2006 \mathrm{IT}=3$ and severity $50-60 \%$, in 2016-70-80\%. For cultivars with gene $\mathrm{Sr} 31$ (Prokhorovka), already in 2006, 0/3 single pustules reaction was observed (Sibikeev et al., 2008, 2009, 2017b). The fact that the field evaluation of these cultivars in 2016 and 2017 showed their susceptibility to the Saratov population of the pathogen, as well as to the Derbent and Lysogorsk populations of $P$. graminis in the laboratory conditions (see Table 1) shows the loss of efficiency of both the gene $\mathrm{Sr} 6 \mathrm{Ag}^{i}$ 
Table 1. Results of phytopathological analysis and identification of Sr genes in the cultivars

\begin{tabular}{|c|c|c|c|c|c|}
\hline \multirow[t]{3}{*}{ Cultivar } & \multicolumn{4}{|c|}{ Resistance to $P$. graminis } & \multirow[t]{3}{*}{ Identified genes } \\
\hline & \multirow{2}{*}{$\begin{array}{l}\text { Saratov population } \\
\text { (field evaluation)* }^{*}\end{array}$} & \multicolumn{3}{|c|}{ Laboratory evaluation to $P$. graminis populations at the seedling stage } & \\
\hline & & I & II & III & \\
\hline Saratovskaya 55 & $70 \mathrm{~S}$ & $3-$ & 2 & 2 & - \\
\hline Saratovskaya 68 & $60 \mathrm{~S}$ & 3 & 3 & $x$ & - \\
\hline Saratovskaya 70 & $70 \mathrm{~S}$ & 3 & 3 & $2-$ & - \\
\hline Saratovskaya 73 & $60 \mathrm{~S}$ & 3 & $2+3$ & $2-$ & - \\
\hline Albidum 32 & $70 \mathrm{~S}$ & 3 & 4 & $2+4$ & - \\
\hline Prokhorovka & $\mathrm{R}$ and $3 \mathrm{~S}$ & 1 & $1 ;$ & $1 ; 2+$ & Sr31 \\
\hline Yugo-Vostochnaya 2 & $\mathrm{R}$ and $3 \mathrm{~S}$ & 0 & 0 & $1-$ & Sr31 \\
\hline Dobrynya & MS, $25 \mathrm{~S}$ & 2 & $2-$ & $2+3+$ & Sr25 \\
\hline Favorit & $75 S$ & 3 & 3 & 0 & $\operatorname{Sr} 6 A g^{i * *}$ \\
\hline Voevoda & $75 S$ & $3=$ & $3+$ & $23-$ & $\operatorname{Sr} 6 A g^{i * *}$ \\
\hline Lebyodushka & $70 S$ & 4 & $3-$ & $2-$ & $\operatorname{Sr} 25+\operatorname{Sr} 6 A g^{i * *}$ \\
\hline
\end{tabular}

Notes: I - Derbent pathogen population; II - Lysogorsk pathogen population (from cultivar Favorit); III - Omsk pathogen population; ${ }^{*}$ degree of development in 2016, type of reaction; ${ }^{* *}$ according to (Sibikeev et al., 2017a).

Table 2. Results of phytopathological analysis and identification of $\mathrm{Sr}$ genes (susceptible lines)

\begin{tabular}{|c|c|c|c|c|c|}
\hline \multirow[t]{3}{*}{ Pedigree } & \multicolumn{4}{|c|}{ Resistance to $P$. graminis populations } & \multirow{3}{*}{$\begin{array}{l}\text { Identified } \\
\text { genes }\end{array}$} \\
\hline & \multirow{2}{*}{$\begin{array}{l}\text { Saratov population } \\
\text { (field) }\end{array}$} & \multicolumn{3}{|c|}{ at the seedling stage } & \\
\hline & & 1 & II & III & \\
\hline Dobr*5//Milan/Prinia L653 & $15 \mathrm{MR}$ & $2+$ & $3-$ & 1 & Sr25 \\
\hline Dobr*5//Milan/Prinia L654 & $15 \mathrm{MR}$ & 0 & $3-$ & 2 & Sr25 \\
\hline S55/Agr.el*4//S29/3/L1015 ?Ag ${ }^{\mathrm{e}}(3 \mathrm{~B}) / ? \mathrm{Ag}^{\mathrm{e}}$ (3D) & $\mathrm{R}, 10 \mathrm{MR}$ & 0 & $3-$ & $2+$ & Sr25 \\
\hline L505*2//L503*2/Kukushka L195 & $10 \mathrm{MR}$ & 4 & 3 & 4 & - \\
\hline Dobr/Prokh//Dobr & $\mathrm{R}$ & 2 & $3-$ & 1 & $S r 25$ \\
\hline S55/Agr. el *6//S29 & $10 \mathrm{MR}$ & 2 & $2+$ & 3 & Sr25 \\
\hline Dobr*4/Nik & $\mathrm{R}$ & 0 & $3-$ & $x$ & $S r 25$ \\
\hline Dobr*4/3/Croc/Ae.squar(205)//Weaver & $20 \mathrm{MR}$ & 2 & 3 & $2-$ & $\operatorname{Sr} 25$ \\
\hline Croc/Ae.squar(205)//Weaver/3/L505/4/DobrLr25 & $20 \mathrm{MR}$ & $2++$ & 3 & 2 & $S r 25$ \\
\hline S55/Agr. el *5//S29(? Age-7D)/3/S68 & $15 \mathrm{MR}$ & $x$ & $3-$ & $2+$ & $S r 25$ \\
\hline S55/Agr. el *5//S29(? Ag $\left.{ }^{e}-7 D\right) / 3 / S 68$ & $15 \mathrm{MR}$ & 2 & 3 & $x$ & $S r 25$ \\
\hline Bel/3/Altar84/Ae.squar(224)//Pgo/4/S68(L481/16) & $20 M R$ & $2++$ & $3+$ & 1 & Sr25 \\
\hline Dobr//6R/Agis181(L426/16) & $\mathrm{R}$ & 1 & $3-$ & 1 & - \\
\hline DobrLr25/Bel//L505 & 20MR & $3=$ & 3 & $2-$ & $\operatorname{Sr} 25$ \\
\hline Dobr/Zol.volna//Dobr/3/Dobr & $\mathrm{R}$ & 4 & 2 & $2-$ & $S r 25$ \\
\hline S55/Agr. el *6//S29 & $\mathrm{R}$ & $3-$ & $2+$ & 1 & Sr25 \\
\hline Prokh*2/L164*2//L164 & $\mathrm{R}$ & $3-$ & $2+$ & 1 & $\operatorname{Sr} 25$ \\
\hline Croc/Ae.squar//Weaver/3/*4L505/4/S73 & $\mathrm{R}$ & $2 ;$ & $3-$ & 2 & $\operatorname{Sr} 25$ \\
\hline $\mathrm{S} 70 * 4 / 3 / \mathrm{Croc} /$ Ae.squar(224)//Yaco & $\mathrm{R}$ & 3 & 3 & 2 & $\operatorname{Sr} 25$ \\
\hline S55/Agr. el *6//S29 & $15 \mathrm{MR}$ & $2+$ & 23 & 2 & Sr25 \\
\hline Lyud//S55*2/T.dic-s//S.zol./L164//S55 & $10 \mathrm{MR}$ & 2 & $2+3$ & $2+$ & $5 r 25$ \\
\hline L528//S55*4/T.dic-s & $\mathrm{R}$ & $2++$ & $2-3$ & 1 & Sr25 \\
\hline S74/T.dicoccum k7507*3//S73 & $\mathrm{R}$ & 0 & 32 & $x$ & $\operatorname{Sr} 25$ \\
\hline LC-SR25-ARS & - & 12 & $3-$ & 12 & $\operatorname{Sr} 25$ \\
\hline
\end{tabular}

Notes: I - Derbent pathogen population; II - Lysogorsk pathogen population (inoculum from cultivar Favorit); III - Omsk pathogen population; \# control line with Sr25. 
Table 3. Identification of $\mathrm{Sr}$ genes in resistant lines

\begin{tabular}{|c|c|c|c|}
\hline Lineage & Srgenes & Lineage & Srgenes \\
\hline L2032*6/Curinda87 & $\operatorname{Sr} 25+\operatorname{Sr} 31$ & Sar.zol/T.dic-s//S58/3/*2 Bel/4/Voevoda & $\operatorname{Sr} 25+\operatorname{Sr} 31$ \\
\hline Dobrynya*4/TsLr25 & $\operatorname{Sr} 25$ & L503Lr26/Ottan(RI1,Rl2)//Revansh & $\operatorname{Sr} 25$ \\
\hline L503Lr19Lr26 & $\operatorname{Sr} 25+\operatorname{Sr} 31$ & L18(L503Lr26)/S68//Revansh & $\operatorname{Sr} 25+\operatorname{Sr} 31$ \\
\hline L505//L503//L583/Kukushka//L505L200 & $\operatorname{Sr} 25$ & Tulaykovskaya10//Agis181/S29+Agis181/S58 & $\operatorname{Sr} 25+\operatorname{Sr} 31+\operatorname{Sr} 28$ \\
\hline S55*3/T.dic-s//L2032 & Sr31 & ThatcherLr37*4/L503 & $\operatorname{Sr} 25$ \\
\hline L2032*5/Seri82 & $\operatorname{Sr} 25+\operatorname{Sr} 31$ & L503Lr26/Ottan(RI1,Rl2)//Revansh & $\operatorname{Sr} 25+\operatorname{Sr} 31$ \\
\hline L505*2//Croc/Ae.squar(224)//Yaco & $\operatorname{Sr} 25+\operatorname{Sr} 57$ & Yu-V-2/L505//L503Lr26/3/L505/4/S68 & $\operatorname{Sr} 25+\operatorname{Sr} 31$ \\
\hline L505/3/Croc/Ae.squar(205)//Weaver/4/L505/5/S68 & $\operatorname{Sr} 25+\operatorname{Sr} 31$ & Milan/Prinia//*4Dobr/3/Favorit & $\operatorname{Sr} 25$ \\
\hline L505/3/Croc/Ae.squar(205)//Weaver/4/L505/5/L505 & $\operatorname{Sr} 25+\operatorname{Sr} 31$ & $\begin{array}{l}\text { Tselinnaya20/Dobr//Dobr/3/DobrLr9/4/Milan/ } \\
\text { Prinia//*4Dobr }\end{array}$ & $\operatorname{Sr} 25+\operatorname{Sr} 38$ \\
\hline Bel/3/Croc/Ae.squar(205)//Weaver/4/Bel & Sr31 & Dobr*5//Milan/Prinia/3/Belyanka/4/S68 & $\operatorname{Sr} 25$ \\
\hline L12(DobrLr24)/S68//S68 & $\operatorname{Sr} 25$ & L503/Sr35//L503/3/L503 & $\operatorname{Sr} 25$ \\
\hline L505*2/Prokh//Bel(L496/16) & $\operatorname{Sr} 31$ & Satu/S70//S74/3/S74 & - \\
\hline S55*3/T.dic-s//L2032(L501/16) & $\operatorname{Sr} 31$ & Sar.zol/T.dic-s//S58/3/*2Bel/4/Voevoda & $\operatorname{Sr} 25+\operatorname{Sr} 31$ \\
\hline Dobr/Zol.volna//DobrLr24/3/Dobrynya & Sr25 & L503Lr26/Ottan(RI1,Rl2)//Revansh & $\operatorname{Sr} 25$ \\
\hline Prokh/MultiLr6R//S68/3/Dobr & Sr25 & L18(L503Lr26)/S68//Revansh & $\operatorname{Sr} 25+\operatorname{Sr} 31$ \\
\hline L505/S42/4/L505*3//Prokh//L505/3/S70/4/DobrLr24 & $\operatorname{Sr} 25+\operatorname{Sr} 31$ & Tulaykovskaya10//Agis181/S29+Agis181/S58 & $\operatorname{Sr} 25+\operatorname{Sr} 31+\operatorname{Sr} 28$ \\
\hline L505/L164/4/L503//Trap\#1/Bow/3/L503/5/L505/6/S68 & $\operatorname{Sr} 25+\operatorname{Sr} 31$ & ThatcherLr37*4/L503 & $\operatorname{Sr} 25$ \\
\hline Yu-V-2/L505//L503Lr26/3/L505/4/S68 & $\operatorname{Sr} 25+\operatorname{Sr} 31$ & L503Lr26/Ottan(RI1,Rl2)//Revansh & $\operatorname{Sr} 25+\operatorname{Sr} 31$ \\
\hline Croc/Ae.squar(205)//Weaver/3/L505/4/DobrLr25 & $\operatorname{Sr} 25$ & Yu-V-2/L505//L503Lr26/3/L505/4/S68 & $\operatorname{Sr} 25+\operatorname{Sr} 31$ \\
\hline Croc/Ae.squar(205)//Weaver/3/L505/4/Bel & $\operatorname{Sr} 25+\operatorname{Sr} 31$ & Milan/Prinia//*4Dobr/3/Favorit & $\operatorname{Sr} 25$ \\
\hline Dobr*5/TcLr9//L505//L503*3/TRAP =BOW//Prokh/S55 & $\operatorname{Sr} 25+\operatorname{Sr} 31$ & $\begin{array}{l}\text { Tselinnaya20/Dobr//Dobr/3/DobrLr9/4/Milan/ } \\
\text { Prinia//*4Dobr }\end{array}$ & $\operatorname{Sr} 25+\operatorname{Sr} 38$ \\
\hline Dobr*5//Milan/Prinia/3/Belyanka/4/S68 & Sr25 & L503/Sr35//L503/3/L503 & $\operatorname{Sr} 25$ \\
\hline
\end{tabular}

from the $\mathrm{Ag}$. intermedium and gene $\mathrm{Sr} 25$ on the territory of the Volga Region. This is consistent with the data of Vasilova and co-authors on the loss of efficiency of the genes $\mathrm{Sr} 6 \mathrm{Ag}^{i}$ and $\operatorname{Sr} 25$ during stem rust epiphytoties in 2016 in Tatarstan (Vasilova et al., 2017). However, under stem rust epiphytoties in 2013-2015 in the Novosibirsk region, the gene $\mathrm{Sr} 6 \mathrm{Ag}^{i}$ $(\mathrm{SrBel})$ inhibited the development of the disease in cultivar Favorit (type of reaction to the pathogen R) (Sochalova, 2016). This agrees with the evaluation data of the cultivar Favorit resistance to the Omsk population of the pathogen at the seedling stage (see Table 1). According to our data, gene Sr31 still retains its effectiveness.

The whole set of introgressive lines, taken in the analysis, was previously evaluated for resistance to the causative agent of stem rust under strong epiphytoties conditions in 2016 in the experimental field of the Laboratory of Genetics ARISER, Saratov, and in the phytonurseries, located in the South-West of the Saratov oblast. As already noted, the degree of disease development in cultivars Favorit and Voevoda reached $80 \%$, which led to significant yield losses (Sibikeev, unpubl. data). The IT in the studied set of lines mainly ranged from 0 to 2 (R, MR). In 2017 during the field evaluation, the lines were also resistant to pathogen, however, during the laboratory evaluation, 15 lines showed susceptible type of reaction (3) to inoculums of the Lysogorsk pathogen population taken from the cultivar Favorit (Table 2). Perhaps this is due to the fact that the pathogen population from the cultivar Favorit is $100 \%$ virulent to $\mathrm{Sr}_{\mathrm{A}} \mathrm{Ag}^{i}$.

As can be seen from the table, only the gene $\mathrm{Sr} 25$ was identified in all susceptible lines, which indicates a loss in the efficiency of this gene. However, the combination of gene Sr 25 with the genes $\operatorname{Sr} 31 / \operatorname{Lr} 26, \operatorname{Sr} 38 / \operatorname{Lr} 37$ and the adult resistant gene $S r 57 / L r 34$ provided resistance to all populations of $P$. graminis taken in the analysis.

Lines resistant to all populations of the pathogen, with the identified $\mathrm{Sr}$ genes are presented in Table 3. The phytopathological evaluation of these lines is provided in the Suppl. Material 6.

Of interest are the spring bread wheat lines shown in Table 3, resistant to all populations of the pathogen, but with an identified $\operatorname{Sr} 25$ gene. The analysis of these lines lineages suggests that they contain other resistance genes. Thus, the cultivars Prinia and Weaver carry the 1 RS.1BL translocation (Sr31) according to the GRIS database (Genetic Resources 
Information System for Wheat and Triticale). It is possible that the gene $\mathrm{Sr} 31$ is present in the lines with the participation of these cultivars, but they are heterogeneous according to this gene. The cultivar Dobrynya, participating in the lineage of resistant lines in which only $\mathrm{Sr} 25$ was identified, was heterogeneous in resistance to the Saratov (field) and Omsk populations of the pathogen and resistant to the Derbent and Lysogorsk populations (see Table 1). Probably, besides $S r 25$, there are other genes in it that influence the manifestation of the trait. In addition, the lines Dobrynya Lr24, Dobrynya Lr25, L503 Lr26 (participating in lineages) and Thatcher Lr37*4/L503 were obtained from crosses with the corresponding isogenic lines of the Thatcher cultivar, which carries the gene complex Sr5 + Sr9g + Sr12 + Sr16 (McIntosh et al., 2013). The possibility of transferring these genes or their combination in a hybrid progeny is not excluded. As can be seen from the lineage, in the line (L503/Sr35//L503/3/L503) the presence of the Sr35 gene is possible, it will be clarified in the further research.

\section{Conclusion}

Thus, genes Sr31 and Sr25 were mainly identified in the analyzed introgression lines. The combination of these genesSr31/Lr26 + Sr25/Lr19 was identified in 15 lines (26.3\%). The combination of genes $\operatorname{Sr} 38 / \mathrm{Lr} 37+\operatorname{Sr} 25 / \mathrm{Lr} 19$ was identified in one line; $\operatorname{Sr} 31 / \mathrm{Lr} 26+\operatorname{Sr} 25 / \mathrm{Lr} 19+\operatorname{Sr} 28$ - in one line; gene Sr25/Lr19 with the adult resistant gene Sr57/Lr34 - in one line. These lines were resistant to all analyzed populations of the pathogen, which makes them promising for further use in breeding. The genes $S r 2, \operatorname{Sr} 24, \operatorname{Sr} 26, \operatorname{Sr} 32, \operatorname{Sr} 36, \operatorname{Sr} 39$ were not detected in the analyzed lines. It is also necessary to note the promising use of triticale cultivar Satu, which carries the genes linkage $\mathrm{LrSatu} / \mathrm{SrSatu}$, in protection against stem rust pathogen (McIntosh et al., 1995).

\section{References}

Ali N., Heslop-Harrison J.S., Ahmad H., Graybosch R.A., Hein G.L., Schwarzacher T. Introgression of chromosome segments from multiple alien species in wheat breeding lines with wheat streak mosaic virus resistance. Heredity (Edinb). 2016;117:114-123. DOI 10.1038/ hdy.2016.36.

Badaeva E.D., Ruban A.S., Shishkina A.A., Sibikeev S.N., Druzhin A.E., Surzhikov S.A., Dragovich A.Yu. Genetic classification of Aegilops columnaris Zhuk. $\left(2 n=4 x=28, \mathrm{U}^{\mathrm{c}} \mathrm{U}^{\mathrm{c}} \mathrm{X}^{\mathrm{c}} \mathrm{X}^{\mathrm{c}}\right)$ chromosomes based on FISH analysis and substitution patterns in common wheat Ae. columnaris introgression lines. Genome. 2018;61(2):131-143.

Baranova O.A., Lapochkina I.F., Anisimova A.V., Gajnullin N.R., Iordanskaya I.V., Makarova I.Yu. Identification of $\mathrm{Sr}$ genes in new common wheat sources of resistance to stem rust race Ug99 using molecular markers. Russ. J. Genet.: Appl. Res. 2016;6(3):344-350. DOI 10.1134/S2079059716030011.

Bhattacharya S. Deadly new wheat disease threatens Europe's crops. Nature. 2017;542:145-146.

Hailu E., Woldaeb G., Denbel W., Wubishet Alemu, Tekelay Abebe, Agengehu Mekonnen. Distribution of stem rust (Puccinia graminis f. sp. tritici) races in Ethiopia. Plant. 2015;3(2):15-19. DOI 10.11648/j.plant.20150302.11.

Jin Y., Singh R.P., Ward R.W., Wanyera R., Kinyua M., Njau P., Fetch T., Pretorius Z.A., Yahyaoui A. Characterization of seedling infection types and adult plant infection responses of monogenic $\mathrm{Sr}$ gene lines to race TTKS of Puccinia graminis f. sp. tritici. Plant Dis. 2007;91:1096-1099.

Koyshybayev M. Features of the development of rust and Septoria leaf spot on spring wheat in Northern Kazakhstan. Zashchita i Karantin
Rasteniy $=$ Plant Protection and Quarantine. 2017;11:21-24 (in Russian)

Lapochkina I.F., Baranova O.A., Shamanin V.P., Volkova G.V., Gainullin N.R., Lazareva E.N., Gladkova E.V., Anisimova A.V., Galinger D.N., Vaganova O.F. The development of the initial material of spring common wheat for selective breeding for resistance to stem rust (Puccinia graminis Pers. f. sp. tritici), including the Ug99 race in Russia. Russ. J. Genet.: Appl. Res. 2017;7(3):308-317. DOI 10.1134/S207905971703008X.

Leonova I.N. Molecular markers: implementation in crop plant breeding for identification, introgression, and gene pyramiding. Russ. J. Genet.: Appl. Res. 2013;3(6):464-473. DOI 10.1134/ S2079059713060051.

Leonova I.N., Budashkina E.B. The study of agronomical traits determining the productivity of the Triticum aestivum/Triticum timopheevii introgression lines with resistance to fungal diseases. Russ. J. Genet.: Appl. Res. 2017;7(3):299-307. DOI 10.1134/ S2079059717030091.

Lewis C.M., Persoons A., Bebber D.P., Kigathi R.N., Maintz J., Findlay K., Corredor-Moreno P., Harrington S.A., Kangara N., Berlin A., Garcia R., German S.E., Hanzalova A., Hodson D., Hovmoller M.S., Huerta-Espino J., Imtiaz M., Iqbal Mirza J., Justesen A.F., Niks R.E., Omarani A., Patpour M., Pretorius Z.A., Roohparvar R., Sela H., Singh R.P., Steffenson B., Visser B., Fenwick P.M., Thomas J., Wulff B.B., Saunders D.G.O. Potential for re-emergence of wheat stem rust in the United Kingdom. Communications Biology. 2018;1:13. DOI 10.1038/s42003-018-0013-y.

Markelova T.S. Phytosanitary situation in the agrocenosis of grain crops in the Volga Region. Zashchita i Karantin Rasteniy = Plant Protection and Quarantine. 2015;5:22-23 (in Russian)

McIntosh R.A., Wellings C.R., Park R.F. (Eds.). Wheat Rusts. An Atlas of Resistance Genes. CSIRO Australia, 1995.

McIntosh R.A., Yamazaki Y., Dubcovsky J., Rogers J., Morris C., Somers D.J., Appels R., Devos K.M. Catalogue of Gene Symbols for Wheat. 2013. http://www.shigen.nig.ac.jp/wheat/komugi/genes/ symbolClassList.jsp

Miedaner T., Korzun V. Marker-assisted selection for disease resistance in wheat and barley breeding. Phytopathology. 2012;102:560-566. DOI 10.1094/PHYTO-05-11-0157.

Murray M.G., Thompson W.F. Rapid isolation of high molecular weight plant DNA. Nucleic Acids Res. 1980;8(19):4321-4326. DOI 10.1093/nar/8.19.4321.

Olivera P., Newcomb M., Flath K., Sommerfeldt-Impe N., Szabo L., Carter M., Luster D., Jin Y. Characterization of Puccinia graminis f. sp. tritici isolates derived from an unusual wheat stem rust outbreak in Germany in 2013. Plant Pathol. 2017;66:1258-1266. DOI 10.1111/ppa.12674.

Pretorius Z.A., Singh R.P., Wagoire W.W., Payne T.S. Detection of virulence to wheat stem rust resistance genes Sr31 in Puccinia graminis f. sp. tritici in Uganda. Plant Dis. 2000;84(2):203. DOI 10.1094/PDIS.2000.84.2.203B.

Rakszegi M., Molnár I., Lovegrove A., Darko E., Farkas A., Lang L., Bedo Z., Dolezel J., Molnar-Lang M., Shewry P. Addition of Aegilops $\mathrm{U}$ and $\mathrm{M}$ chromosomes affects protein and dietary fiber content of wholemeal wheat flour. Front. Plant Sci. 2017;8:1529. DOI 10.3389/fpls.2017.01529.

Roelfs A.P., Singh R.P., Saaru E.E. Rust Diseases of Wheat: Concepts and Methods of Disease Management. Mexico, D.F.: CIMMYT, 1992.

Salina E.A., Adonina I.G., Badaeva E.D., Kroupin P.Y., Stasyuk A.I., Leonova I.N., Shishkina A.A., Divashuk M.G., Starikova E.V., Khuat T.M.L., Syukov V.V., Karlov G.I. A Thinopyrum intermedium chromosome in bread wheat cultivars as a source of genes conferring resistance to fungal diseases. Euphytica. 2015;204:91-101. DOI 10.1007/s10681-O14-1344-5.

Sibikeev S.N., Druzhin A.E., Golubeva T.D., Kalintseva T.V. The evaluation of spring bread wheat cultivars, NILs and promise lines to stem rust. Annual Wheat Newsletter. KSU, USA. 2008;54:113. 
Sibikeev S.N., Druzhin A.E., Golubeva T.D., Kalintseva T.V. The evaluation of spring bread wheat cultivars, NILs and promise lines to leaf, stem and stripe rusts in 2008 year. Annual Wheat Newsletter. KSU, USA. 2009;55:174.

Sibikeev S.N., Druzhin A.E., Badaeva E.D., Shishkina A.A., Dragovich A.Y., Gultyaeva E.I., Kroupin P.Y., Karlov G.I., Khuat T.M., Divashuk M.G. Comparative analysis of Agropyron intermedium (Host) Beauv $6 \mathrm{Ag}^{\mathrm{i}}$ and $6 \mathrm{Ag}^{\mathrm{i} 2}$ chromosomes in bread wheat cultivars and lines with wheat-wheatgrass substitutions. Russ. J. Genet. 2017a;53(3):314-324. DOI 10.1134/S1022795417030115.

Sibikeev S.N., Druzhin A.E., Vlasovec L.T., Golubeva T.D., Kalintseva T.V. The reaction of introgression lines of soft spring wheat to leaf rust, stem rust and tan spot in 2016. Annual Wheat Newsletter. KSU, USA. 2017b;63:57-58.

Singh D., Park R.F., McIntosh R.A., Bariana H.S. Characteristic of stem rust and stripe rust seedling resistance genes in selected wheat cultivars from the United Kingdom. J. Plant Pathol. 2008;90(3): 553-562.
Sochalova L.P. Sources of wheat resistance genes to leaf and stem pathogens on the territory of the Novosibirsk Region. Zernovoe Khozjaistvo Rossii = Grain Economy of Russia. 2016;2:45-49 (in Russian)

Stackman E.C., Stewart D.M., Loegering W.Q. Identification of Physiologic Races of Puccinia graminis var. tritici. US Department of Agriculture; Agric. Res. Service, 1962.

Vasilova N.Z., Askhadullin Dam.F., Askhadullin Dan.F. Stem rust epiphytotic on soft spring wheat in Tatarstan. Zashchita i Karantin Rasteniy = Plant Protection and Quarantine. 2017;2:27-28. (in Russian)

Wulf B.B.H., Moscou J.M. Strategies for transferring resistance into wheat: from wide crosses to GM cassettes. Front. Plant Sci. 2014; 5:692.

Yaniv E., Raats D., Ronin Y., Korol A.B., Grama A., Bariana H., Dubcovsky J., Schulman A.H., Fahima T. Evaluation of marker-assisted selection for the stripe rust resistance gene $\mathrm{Yr} 15$, introgressed from wild emmer wheat. Mol. Breed. 2015;35:43. DOI 10.1007/s11032015-0238-0.

ORCID ID

O.A. Baranova orcid.org/0000-0001-9439-2102

S.N. Sibikeev orcid.org/0000-0001-8324-9765

A.E. Druzhin orcid.org/0000-0002-3968-2470

Acknowledgements. This work was supported by the RFBR grant No. 18-016-00170a.

Conflict of interest. The authors declare no conflict of interest.

Received September 10, 2018. Revised December 24, 2018. Accepted December 26, 2018 